\title{
Use of Antenatal Steroids to Counteract the Negative Effects of Tracheal Occlusion in the Fetal Lamb Model
}

\author{
SAUNDRA KAY, JEAN-MARTIN LABERGE, HELENE FLAGEOLE, SUSANE RICHARDSON, \\ SYLVIE BELANGER, AND BRUNO PIEDBOEUF \\ The Montreal Children's Hospital, Department of Surgery, McGill University, Montreal, Quebec H3H \\ 1P3, Canada [S.K., J.-M.L., H.F.]; Centre Hospitalier de L'Universite Laval, Department of Pediatrics, \\ Universite Laval, Sainte-Foy, Quebec G1V 4G2, Canada [S.R., S.B., B.P.]
}

\begin{abstract}
ABST
Tracheal occlusion (TO) in fetal lambs induces pulmonary
hyperplasia but has negative effects on type II cells. The purpose
of this study was to determine whether antenatal steroids could
reverse the adverse effects of TO on lung maturation in fetal
lambs. Sixteen time-dated pregnant ewes (term, $145 \mathrm{~d}$ ) and 24 of
their fetuses were divided into six groups: 1 ) TO at $117 \mathrm{~d}$
gestation; 2 ) TO at $117 \mathrm{~d}$ with a single maternal intramuscular
injection of 0.5 mg/kg betamethasone $24 \mathrm{~h}$ before delivery; 3 )
TO at $117 \mathrm{~d}$ and release of the occlusion $2 \mathrm{~d}$ before delivery; 4 )
TO and release of the occlusion with maternal steroids; 5 )
unoperated controls without antenatal steroid treatment; and 6 )
unoperated controls, littermates of groups $1-4$, treated with
antenatal steroids. All fetuses were killed at $137 \mathrm{~d}$ gestation.
Outcome measurements consisted of lung weight-to-body
weight ratio; lung morphometry determined by mean terminal
bronchial density; and assessment of type II pneumocytes by in
situ hybridization to the mRNA of surfactant proteins B and C.
Lung weight-to-body weight ratio and mean terminal bronchial
density were significantly different among groups with TO and
controls, indicating increased lung growth and structural matu-
\end{abstract}
ration. The density of type II pneumocytes was markedly decreased by TO. Release $2 \mathrm{~d}$ before sacrifice significantly increased the density and surfactant activity of type II pneumocytes, but to levels still far from controls. Steroids alone had an effect similar to release. An additive effect was noted with steroids and 2-d release resulting in type II cell density comparable to controls. After fetal TO, a single maternal intramuscular dose of $0.5 \mathrm{mg} / \mathrm{kg}$ of betamethasone $24 \mathrm{~h}$ before delivery allows partial recuperation of the type II pneumocytes, an effect that is potentiated by 2-d release. (Pediatr Res 50: 495-501, 2001)
TO, fetal tracheal occlusion
Abbreviations
$\mathbf{S}$, antenatal steroids
$\mathbf{R}$, release of the tracheal occlusion
SP-C, surfactant protein C
SP-B, surfactant protein B
MTBD, mean terminal bronchial density
wLW/BW, wet lung weight-to-body weight ratio
dLW/BW, dry lung weight-to-body weight ratio

Congenital diaphragmatic hernia remains an important cause of neonatal morbidity and mortality despite advances in neonatal care (1-3). Pulmonary hypoplasia, pulmonary hypertension, and surfactant deficiency are all major contributors, although the degree of pulmonary hypoplasia is the most important predictor of survival $(4-8)$.

TO has been shown to accelerate fetal lung growth, resulting in hyperplastic lungs (9-12). These lungs, however, were discovered to be deficient in type II pneumocytes and thus surfactant (13-16). We have previously shown that releasing the occlusion 1

Received July 27, 1999; accepted February 16, 2000.

Correspondence and reprint requests: Bruno Piedboeuf, M.D., Centre de Recherche du Pavillon CHUL, Centre Hospitalier Universitaire de Quebec, 2705, boulevard Laurier, Sainte-Foy, Quebec G1V 4G2, Canada; e-mail: Bruno.Piedboeuf@crchul.ulaval.ca

Supported by grants from the Montreal Children's Hospital Research Institute and the Fondation de la Recherche sur les Maladies Infantiles. B.P. was supported by an award from the Fondation de la Recherche en Sante du Quebec. wk before delivery results in a full recovery of type II pneumocytes (17). Partial recovery of the type II pneumocytes is seen with release of the occlusion $2 \mathrm{~d}$ before delivery (17).

The disadvantages of requiring a tracheal release procedure so close to term are evident, with risks of premature labor and fetal death. The possibility of avoiding such an intervention, by finding an alternative means of achieving type II cell maturation, was explored. Antenatal steroids were considered. They are given routinely to women in premature labor to accelerate fetal lung maturation and thus avoid respiratory distress syndrome in their premature newborns $(18,19)$. Also, some animal studies have demonstrated a beneficial effect of antenatal corticosteroids on lung maturation and compliance, with increases in surfactant markers in premature and hypoplastic lung models (20-23).

We thus set out to determine whether antenatal corticosteroids alone or in combination with tracheal release $2 \mathrm{~d}$ before 
delivery could reverse the negative effects of TO on type II pneumocytes in the fetal lamb model.

\section{METHODS}

Fetal surgical procedure. Time-dated pregnant mixed-breed ewes were obtained $(n=16)$. The fetal lambs $(n=24)$ were divided into six groups. Group $1(n=4)$ underwent TO, either by ligation or balloon. Group $2(n=4)$ also underwent TO, but the ewe was administered a dose of betamethasone (S) $24 \mathrm{~h}$ before sacrifice. Group $3(n=3)$ underwent TO and release of the occlusion (R) $2 \mathrm{~d}$ before sacrifice. Group $4(n=4)$ was similar to group 3, but the ewe was given betamethasone. Groups $5(n=4)$ and $6(n=5)$ consisted of unoperated on control lambs, littermates of the nonsteroid and steroid groups, respectively. TO procedures were performed at 116-118 d gestation (term, $145 \mathrm{~d}$ ). Tracheal release procedures were performed at 135-137 d gestation, always $2 \mathrm{~d}$ before sacrifice. Steroids were administered to the ewe as a single intramuscular dose of $0.5 \mathrm{mg} / \mathrm{kg}$ of betamethasone $24 \mathrm{~h}$ before delivery. Ewes and fetuses were sacrificed at 137-139 d gestation, except one that was sacrificed at $135 \mathrm{~d}$ in group 1 . All procedures were approved by the McGill University Animal Care Committee.

Details of the operative procedures have been published $(9,17)$. For the TO procedures, the ewe was induced with i.v. pentobarbital, and anesthesia was maintained with halothane. A midline incision was used to gain access to the uterus. Through a small hysterotomy, the fetal neck was opened transversely, and the trachea was isolated. TO was accomplished either by ligation of the trachea or by passage of a Swan-Ganz catheter, tunneled s.c. from the ewe's flank, through a small tracheal puncture, with saline inflation of the balloon until snug. Ligation was used in groups remaining occluded until birth because of the diminished risk of technical failure with this technique. Before closure of the hysterotomy, the uterus was instilled with warm saline, liquamycin, gentamicin, and cefazolin.

The tracheal release procedure was accomplished under i.v. sedation with thiopental and local anesthesia. A small incision was made in the ewe's flank over the end of the Swan-Ganz catheter. The balloon port was opened, the balloon deflated, and the catheter cut, before closing the wound with staples. The ewes were sacrificed using a lethal dose of i.v. pentobarbital, which was also injected into each umbilical cord.

Preparation of the lungs. At sacrifice, the condition of the trachea was noted, and body, lung, liver, and heart weights were recorded. Specimens were taken from the right middle lobe for wet-to-dry lung weight analysis. For this, a small piece of lung tissue was resected, weighed, and left to air-dry for a minimum of $1 \mathrm{wk}$. When completely desiccated, the tissue was reweighed and weighed again $24 \mathrm{~h}$ later to make sure there was no change, and the wet-to-dry ratio thus obtained was used to calculate a total dry lung weight (24-26). The lingula was removed for later electron microscopy (not included in this paper), and the remainder of the lungs was fixed in $10 \%$ formalin at $25 \mathrm{~cm} \mathrm{H}_{2} \mathrm{O}$ pressure for 24-48 h.

Histologic analysis. The formalin-fixed lungs were cut in transverse sections 3-5 mm thick. Random blocks of 1-2 cm were taken from each upper and lower lobe, embedded in paraffin, sectioned $(5 \mu \mathrm{m})$, and stained with hematoxylin and eosin. These slides were used to assess the MTBD, a morphometric method based on the principle that the number of terminal bronchioles in a given high-power field is inversely proportional to the number of alveoli supplied by each bronchiole $(16,27)$. At a magnification of $\times 100,20$ random nonoverlapping fields were examined for each animal (approximately five per lobe). Slides were examined by two observers trained in the technique and blinded to the group being examined.

In situ hybridization. The mRNA of SP-B and SP-C were used as markers of type II pneumocytes. Sheep-specific cDNA probes for SP-B and SP-C were donated by Dr. Fred Possmayer (University of Western Ontario, London, Ontario, Canada). Complementary RNA probes were labeled with $\left[{ }^{3} \mathrm{H}\right]$-uracil triphosphate and $\left[{ }^{3} \mathrm{H}\right]$-cytosine triphosphate (DuPont Canada, Markham, Ontario, Canada) as previously described (28). Hybridization methods have been described previously (13). Hybridization was performed overnight at $54^{\circ} \mathrm{C}$ in $50 \%$ formamide, $0.3 \mathrm{M} \mathrm{NaCl}, 10$ $\mathrm{mM}$ Tris- $\mathrm{HCl}(\mathrm{pH} 8.0), 1 \mathrm{mM}$ EDTA, $1 \times$ Denhardt's solution, $10 \%$ dextran sulfate, $0.5 \mathrm{mg} / \mathrm{mL}$ yeast tRNA, and $120 \mathrm{ng} / \mathrm{mL}$ of cRNA probe in a moist chamber containing $0.3 \mathrm{M} \mathrm{NaCl}$ and $50 \%$ formamide. After hybridization, the sections were treated with RNase. The final wash was performed in $0.1 \%$ SDS for $30 \mathrm{~min}$ at $68^{\circ} \mathrm{C}$. Slides were dipped in NBT-2 photographic emulsion (Eastman Kodak, Rochester, NY, U.S.A.), stored $6 \mathrm{~d}$ for SP-C and $16 \mathrm{~d}$ for SP-B until development, then counterstained with hematoxylin and eosin before photomicrography. Nonspecific binding and background were evaluated using sense probes on one section from each animal. For each animal, one section from at least three different lobes was analyzed. The density of alveolar cells expressing SP-B or SP-C mRNA was evaluated by counting the number of cells expressing SP-B and SP-C mRNAs on five random fields of each section. Cells were considered positive if five or more silver grains were observed over the cell. Bronchial cells expressing SP-B, likely representing Clara cells, were not counted. To account for the variable degree of alveolar distension induced either by $\mathrm{TO}$ or by lung fixation, the data were corrected by dividing the mean density by the tissue-to-air space fraction. This fraction was evaluated by the point-counting method on two fields of each section (29). In addition, the amount of SP-B and SP-C mRNA per cell, a reflection of type II cell activity, was determined for each section by counting the number of silver grains per positive cell in 10 randomly selected type II cells.

Statistical analysis. Results of the wLW/BW and dLW/BW and of the MTBD values were expressed as the mean \pm SEM. These were compared using the Mann-Whitney $U$ test, with $p<0.05$ representing statistical significance.

Results of the in situ hybridization were expressed as mean \pm SEM. To obtain homogeneity of the variances in the statistical analysis, data for the density of SP-B and SP-C positive cells were transformed to a logarithm. Factorial ANOVA was used to compare the different groups. Statistical significance was accepted at $\alpha<0.05$.

\section{RESULTS}

Analysis of the wLW/BW revealed a significant increase in lung weight by TO when compared with control lungs ( $p=$ 
Table 1. Lung weight-to-body weight ratio

\begin{tabular}{clll}
\hline & & \multicolumn{2}{c}{ With steroid } \\
\cline { 3 - 4 } Group & \multicolumn{1}{c}{ No steroid } & wLW/BW & dLW/BW \\
\hline TO & $7.02 \pm 0.32^{*}(n=5)$ & $6.98 \pm 0.44^{*}(n=4)$ & $0.57 \pm 0.05^{*}(n=4)$ \\
TO $+\mathrm{R}$ & $3.93 \pm 0.49 * \dagger(n=3)$ & $3.00 \pm 0.16 \dagger(n=4)$ & $0.57 \pm 0.04 *(n=4)$ \\
Control & $2.62 \pm 0.20(n=5)$ & $3.08 \pm 0.20(n=5)$ & $0.27 \pm 0.03(n=5)$ \\
\hline
\end{tabular}

Lung weight was expressed as a percentage of body weight (mean \pm SEM).

$* p<0.05$ different from controls.

$\dagger p<0.05$ different from TO.

0.02 steroid groups, $p<0.01$ nonsteroid groups). Tracheal release significantly diminished this positive effect on lung growth $(p=$ 0.03 steroid groups, $p=0.04$ nonsteroid groups), but in the nonsteroid groups, $\mathrm{TO}+\mathrm{R}$ lung weights were still significantly higher than those of controls $(p=0.04$; Table 1$)$. To correct for a possible fluid retention effect in the TO groups, the $\mathrm{dLW} / \mathrm{BW}$ was also obtained when possible. This measurement, only available in the three steroid groups, similarly revealed that TO significantly increased lung weight $(p=0.02)$, but release did not significantly alter this positive effect (Table 1).
Results of the lung morphometry study for all groups is shown in Table 2. TO results in significant decreases in the MTBD, signifying increased alveolar development and complexity ( $p=0.03$ steroid groups, $p=0.02$ nonsteroid groups). Tracheal release does not significantly alter this effect, and steroids demonstrate no effect on lung morphometry.

Type II pneumocyte density and function were assessed by in situ hybridization to the mRNA of SP-C and SP-B. Figure 1 shows a typical example of SP-C mRNA expression in these lungs, and Figures 2 and 3 demonstrate the results of the
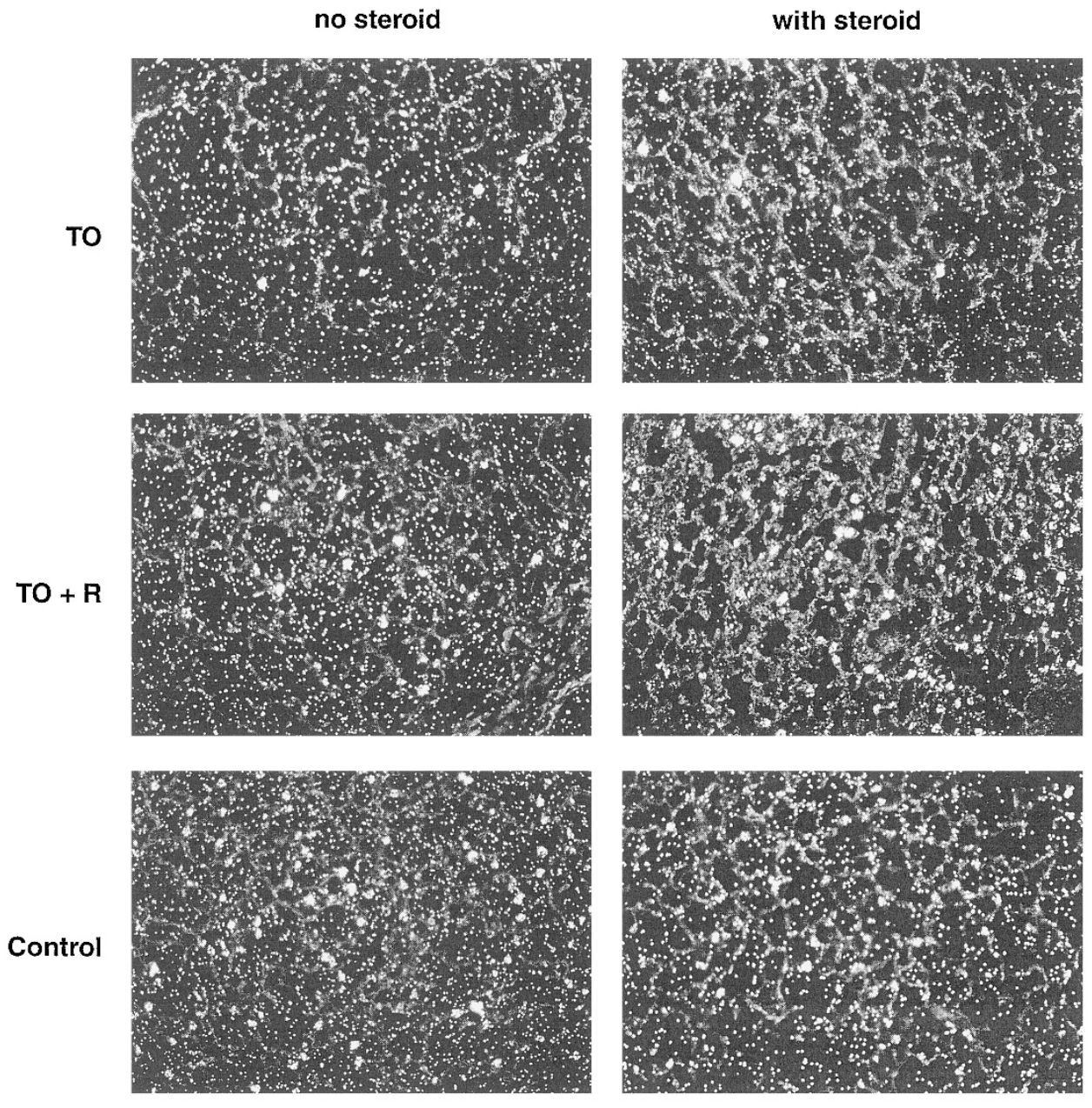

$$
\overline{100 \mu \mathrm{m}}
$$

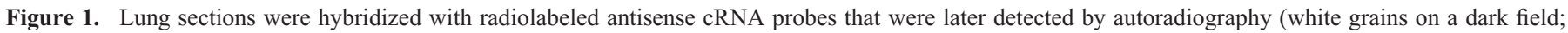

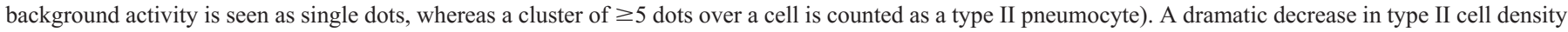

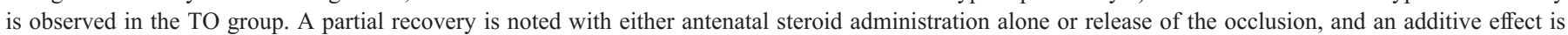
noted with the use of the two together. 
Table 2. Lung morphometry: $M T B D$

\begin{tabular}{lcc}
\hline Group & No steroid & Steroid \\
\hline TO & $1.6 \pm 0.1^{*}(n=4)$ & $1.7 \pm 0.1^{*}(n=4)$ \\
TO $+\mathrm{R}$ & $1.4 \pm 0.2^{*}(n=3)$ & $1.9 \pm 0.3^{*}(n=4)$ \\
Controls & $3.2 \pm 0.1 \quad(n=4)$ & $3.2 \pm 0.2 \quad(n=5)$ \\
\hline
\end{tabular}

MTBD, representing the number of terminal bronchioles per high-power field (mean $\pm \mathrm{SEM}$ ), is inversely proportional to the degree of lung development and complexity.

$* p<0.05$ different from controls.

semiquantitative analysis. TO causes a significant decrease in the density of cells expressing SP-C mRNA when compared with controls $(\alpha<0.01)$. The density of such cells is significantly increased by a 2 -d period of release $(\alpha<0.01)$, although levels are still lower than in control lungs (Fig. 2). Steroids increased the density of SP-C mRNA-positive cells $(\alpha<0.01)$. The combined effect of the release and steroids were additive, bringing the density of type II cells to levels comparable to those of control animals. As for expression of SP-C mRNA per positive cell, $2 \mathrm{~d}$ of release augmented individual cell activity significantly ( $\alpha<0.01$; Fig. 3$)$. Steroid treatment alone also significantly increased the individual cellular expression of SP-C mRNA $(\alpha<0.05)$, although this effect of the steroids was not as pronounced as the augmentation in density of the SP-C-positive cells.

Similar results were obtained for SP-B, with TO resulting in a significant decrease in the density of alveolar cells producing SP-B (Fig. 4). Also, an increase in the density of these cells was noted with $2 \mathrm{~d}$ of release alone $(\alpha<0.01)$ and with steroids alone $(\alpha<0.01)$, the effects of which were additive (Fig. 5). With respect to individual cellular activity, tracheal

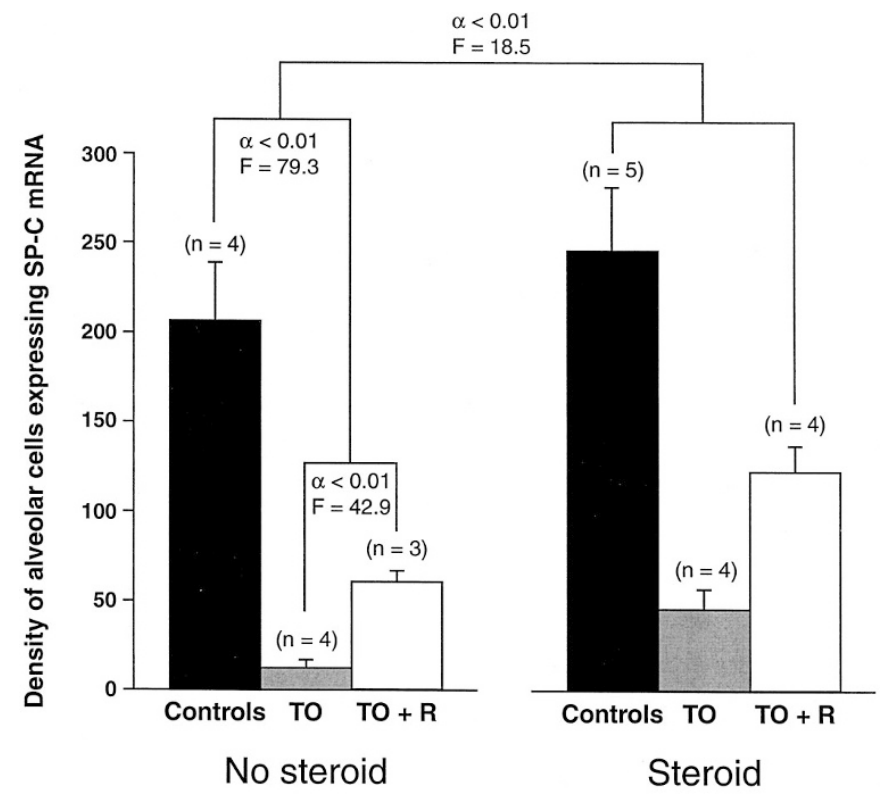

Figure 2. Density of cells expressing SP-C mRNA as determined by in situ hybridization (mean \pm SEM cells per $\times 20$ field). TO results in a dramatic decrease in type II cell density, with a significant recovery noted when the occlusion is released. Furthermore, a significant increase in type II cell density is observed across the groups when steroids are added. $F=4.38$ for an $\alpha=$ $0.05 ; F=8.18$ for an $\alpha=0.01$.

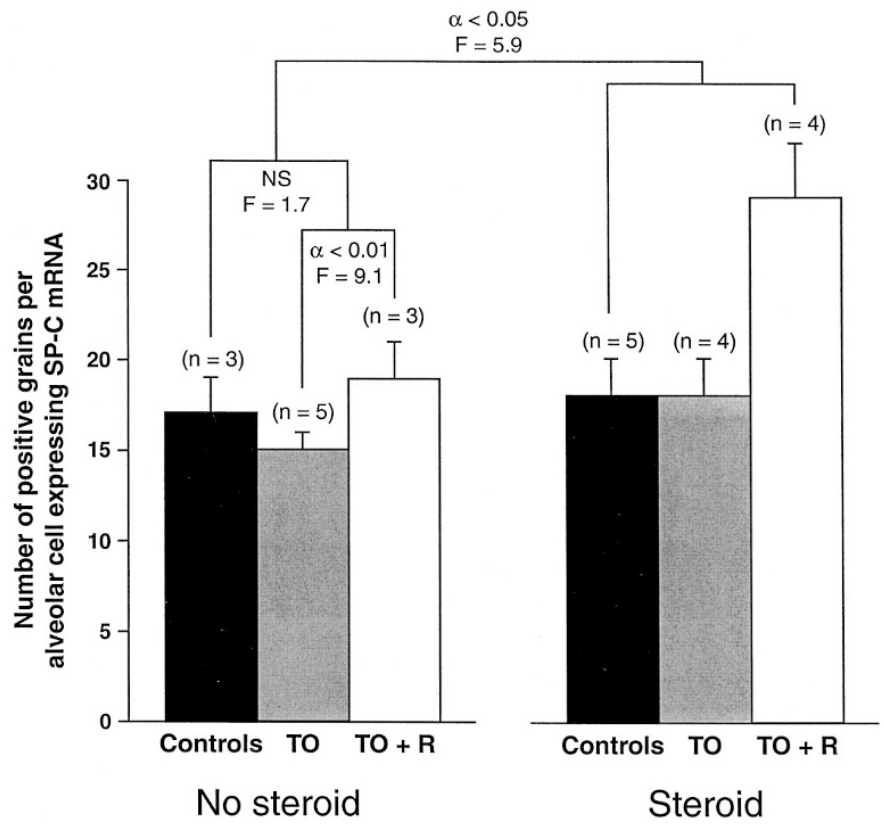

Figure 3. The relative abundance of SP-C mRNA in type II cells, determined by in situ hybridization, is expressed as mean \pm SEM grains/cell. Release of the occlusion results in a significantly increased number of grains per cell. Steroids have a similar effect across the groups. $F=4.38$ for an $\alpha=0.05$; $F=8.18$ for an $\alpha=0.01$.

release resulted in significant increases $(\alpha<0.01)$, but steroids showed no significant effect (Fig. 6).

\section{DISCUSSION}

TO results in hyperplastic lungs with increases in total lung DNA and protein, increased airspaces, and a parallel growth of the pulmonary vasculature $(9-12)$. It thus appears to be a promising treatment strategy for congenital diaphragmatic hernia when the primary problem is one of pulmonary hypoplasia. The mechanism responsible for this accelerated growth is unclear. It has been postulated that distension of the airspaces by the accumulating lung fluid stimulates cell division and that certain growth factors play a role (30-33). As for the deficiency in type II pneumocytes noted in these lungs, it has been suggested that $\mathrm{TO}$, by providing a constant stimulus for growth, drives undifferentiated cells and type II cells to differentiate into type I cells in an accelerated fashion $(17,18)$. Such a phenomenon is seen during times of lung injury, in which the type II cells differentiate into type I cells to reconstitute the alveolar lining (34). The drive for growth may occupy the type II cells, thus preventing them from fulfilling their role of surfactant production.

Regardless of mechanism, efforts have been directed toward prevention of this deleterious effect. Releasing the TO 1 mo before delivery leads to full recovery of type II cells, as does 1 wk of release, with only a partial loss of the growth effects of the occlusion $(16,17)$. By withdrawing the stimulus for accelerated growth, type II cells are able to divert their energy into surfactant production. Recent efforts have been directed toward minimizing the risks of the $\mathrm{TO}$ and release procedures by developing endoscopic surgical techniques $(16,35-37)$. De- 
no steroid
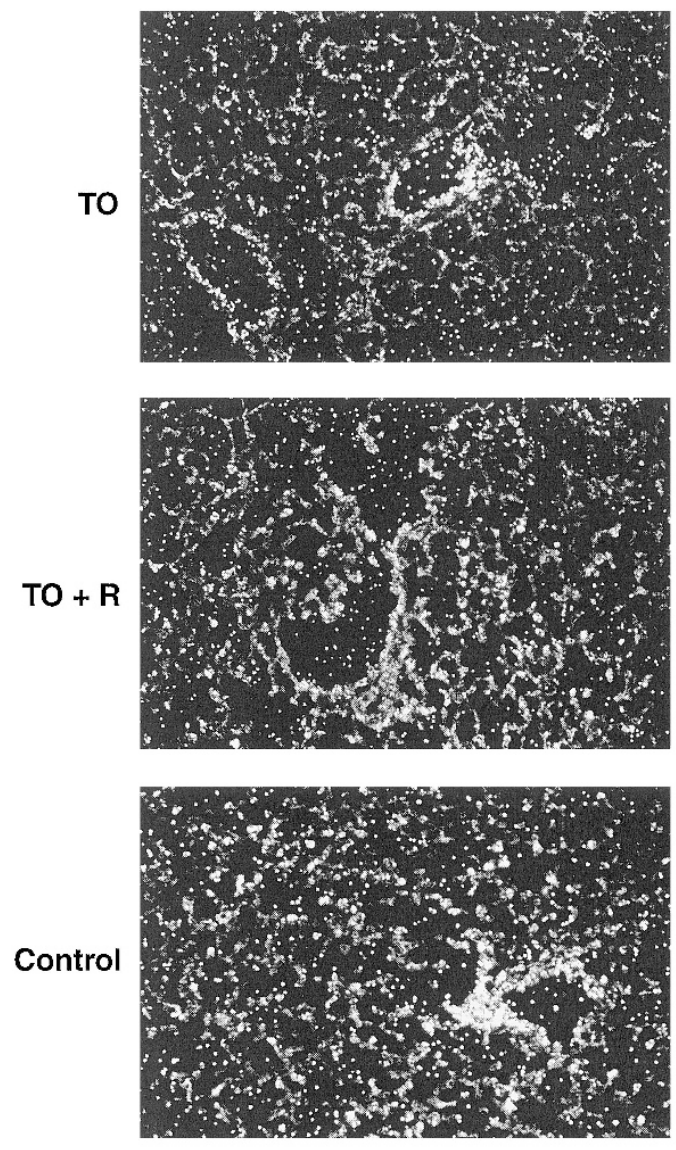

with steroid
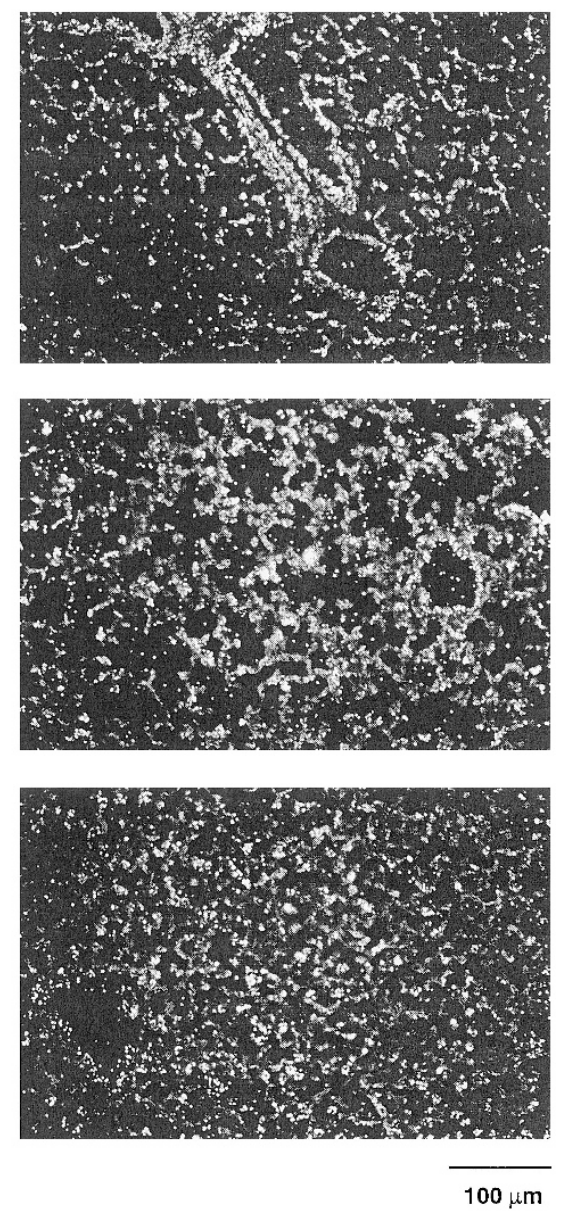

Figure 4. Lung sections were hybridized with radiolabeled antisense cRNA probes that were later detected by autoradiography (white grains on a dark field; background activity is seen as single dots, whereas a cluster of $\geq 5$ dots over a cell is counted as an SP-B-positive cell). TO produces a marked decrease in SP-B-positive cells. Note the relative preservation of SP-B-positive cells lining the bronchioles (representing Clara cells). The administration of steroids or release of the TO results in a partial recovery of SP-B-positive cells, whereas the combination of the two modalities results in a complete recovery.

spite these advances, premature labor remains an important, although certainly diminished, risk $(37,38)$. Avoiding a tracheal release procedure, which is performed so close to term, would be ideal. Inasmuch as steroids are known to accelerate fetal lung maturation in premature infants, we set out to determine whether the same result could be obtained in a TO model. Also, we looked at whether the use of steroids could potentiate the effect of 2-d tracheal release. The potential advantages of a 2-d release period combined with steroids, as opposed to a 1-wk release period, are that the longer occlusion time would allow for greater lung growth, and more importantly, if premature labor were to result from the tracheal release procedure, it would be easier to control labor for $2 \mathrm{~d}$ than for $1 \mathrm{wk}$ while waiting for the type II cells to mature sufficiently. Although earlier studies suggested that, in the sheep, maternally administered steroids did not cross the placenta and thus would not work on the fetus $(39,40)$, recent studies have proven otherwise $(21,41)$. The dose, route of administration, and timing of the steroids given in our study have been shown to have a significant effect on lung maturation in a premature sheep model (21). We did not give a longer course of maternal steroids because of the risk of inducing premature labor and delivery $(39,40)$.

In addition to using the standard wLW/BW to assess lung growth, we calculated and compared the dLW/BW. We feel that this is more accurate because it removes the variable of retained lung fluid. Despite attempts to passively drain the lungs of their fluid at sacrifice, this is almost certainly incomplete.

We chose to use SP-C as the main marker of type II cells because this surfactant protein is produced exclusively in type II cells (42). SP-B was used adjunctively to ensure that the observed effect was not limited only to the SP-C gene. Although SP-B is expressed in bronchial (Clara) cells as well as type II cells (42), only the alveolar expression of SP-B, representing the type II cells, was taken into account in this study.

In contrast with our previous publication, we were able to show a positive effect of 2-d release on both SP-C mRNA activity per cell as well as on the density of SP-C mRNAexpressing cells (17). Our results show that in a TO model, a single maternal intramuscular dose of $0.5 \mathrm{mg} / \mathrm{kg}$ of betamethasone, combined with release of the TO $2 \mathrm{~d}$ before delivery, results in a near complete recovery of the type II pneumocytes. 


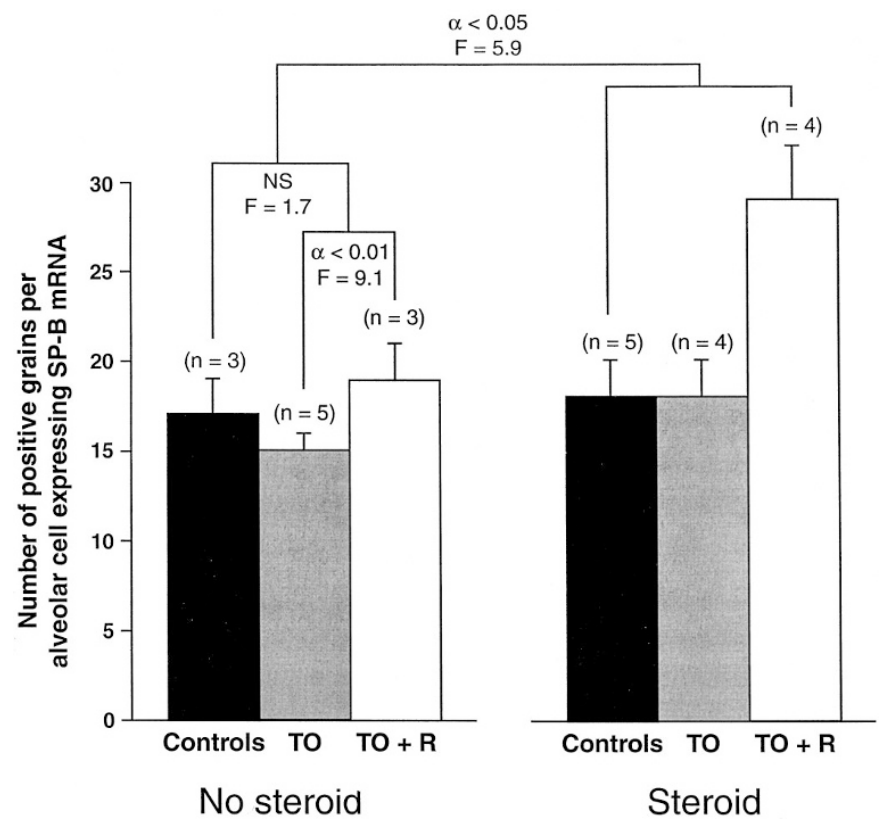

Figure 5. Density of alveolar cells expressing SP-B mRNA as determined by in situ hybridization (mean \pm SEM cells per $\times 20$ field). TO results in a dramatic decrease in SP-B-positive cell density, with a significant recovery noted when the occlusion is released. Furthermore, a significant increase in SP-B-positive cell density is observed across the groups when steroids are added. $F=4.45$ for an $\alpha=0.05 ; F=8.90$ for an $\alpha=0.01$. Bronchial cells expressing SP-B mRNA were not counted.
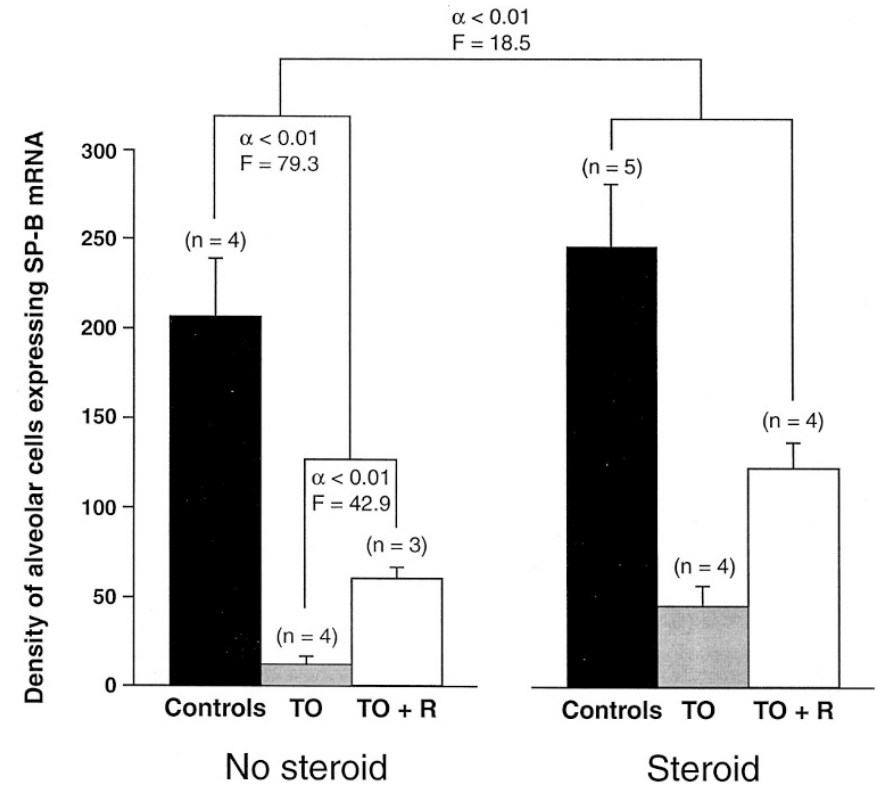

Figure 6. The relative abundance of SP-B mRNA in alveolar cells positive for SP-B, determined by in situ hybridization, is expressed as mean \pm SEM grains/cell. Release of the occlusion results in a significantly increased number of grains per cell. $F=4.38$ for an $\alpha=0.05 ; F=8.18$ for an $\alpha=0.01$. Bronchial cells expressing SP-B mRNA were not taken into account.

Although steroids have been used for many years to accelerate lung maturation in premature labor, their mechanism of action has remained unclear. Most of the studies conducted have looked at the effect of steroids on total levels of SP-B and SP-C mRNAs using Northern blot analysis (43-45). These have demonstrated increased levels, but it was not clear whether this was caused by an increase per cell or an increase in the number of cells expressing the surfactant protein mRNAs. In addition to demonstrating a potential benefit of steroids in the TO model, our results shed some light on the mechanism of action of antenatal steroids to accelerate lung maturation in premature labor. Our study has demonstrated that steroids act rapidly (within $24 \mathrm{~h}$ ) to principally increase the number of cells expressing the surfactant protein mRNAs.

In conclusion, our study demonstrates that antenatal steroids given shortly before birth increase the number and function of type II cells in the lungs of fetal sheep undergoing TO. Unfortunately, steroids alone result in only a partial compensation for the dramatic decrease in type II cells observed with TO. However, the combination of a short period of occlusion release and antenatal steroids is beneficial, and we can speculate that the increased number of type II cells, combined with the increased activity of those cells, will lead to a clinically relevant improvement in surfactant function. This must now be tested in an animal model of congenital diaphragmatic hernia with careful attention paid to surfactant activity and function.

Although TO has been used with some success in human fetuses with congenital diaphragmatic hernia, the deleterious effects on type II cells have not been addressed (46). The optimal treatment of the human fetus with bad-prognosis congenital diaphragmatic hernia should include a reversible method of TO and maternal betamethasone administration.

\section{REFERENCES}

1. Langham MR, Kays DW, Ledbetter DJ, Frentzen B, Sanford LL, Richards DS 1996 Congenital diaphragmatic hernia: epidemiology and outcome. Clin Perinatol 23:671687

2. Irish MS, Holm BA, Glick PL 1996 Congenital diaphragmatic hernia: a historical review. Clin Perinatol 23:625-653

3. Lund DP, Mitchell J, Kharasch V, Quigley S, Kuehn M, Wilson JM 1994 Congenital diaphragmatic hernia: the hidden morbidity. J Pediatr Surg 29:258-264

4. Glick PL, Stannard VA, Leach CL, Rossman J, Hosada Y, Morin FC, Cooney DR, Allen JE, Holm B 1992 Pathophysiology of congenital diaphragmatic hernia II: the fetal lamb CDH model is surfactant deficient. J Pediatr Surg 27:382-388

5. Ting A, Glick PL, Wilcox DT, Holm BA, Gil J, DiMaio M 1998 Alveolar vascularization of the lung in a lamb model of congenital diaphragmatic hernia. Am J Respir Crit Care Med 157:31-34

6. O’Toole SJ, Irish MS, Holm BA, Glick PL 1996 Pulmonary vascular abnormalities in congenital diaphragmatic hernia. Clin Perinatol 23:781-793

7. Wilcox DT, Irish MS, Holm BA, Glick PL 1996 Pulmonary parenchymal abnormalities in congenital diaphragmatic hernia. Clin Perinatol 23:771-779

8. Antunes MJ, Greenspan JS, Cullen RN, Holt WJ, Baumgart S, Spitzer AR 1995 Prognosis with preoperative pulmonary function and lung volume assessment in infants with congenital diaphragmatic hernia. Pediatrics 96:1117-1122

9. Hashim E, Laberge JM, Chen MF, Quillen EW 1995 Reversible tracheal obstruction in the fetal sheep: effects on tracheal fluid pressure and lung growth. J Pediatr Surg 30:1172-1177

10. Wilson JM, DiFiore JW, Peters CA 1993 Experimental fetal tracheal ligation prevents the pulmonary hypoplasia associated with fetal nephrectomy: possible application for congenital diaphragmatic hernia. J Pediatr Surg 28:1433-1440

11. Hedrick MH, Estes JM, Sullivan KM, Bealer JF, Kitterman JA, Flake AW, Adzick NS, Harrison MR 1994 Plug the lung until it grows (PLUG): a new method to treat congenital diaphragmatic hernia in utero. J Pediatr Surg 29:612-617

12. DiFiore JW, Fauza DO, Slavin R, Wilson JM 1995 Experimental fetal tracheal ligation and congenital diaphragmatic hernia: a pulmonary vascular morphometric analysis. J Pediatr Surg 30:917-924

13. Piedboeuf B, Laberge JM, Ghitulescu G, Gamache M, Petrov P, Belanger S, Chen MF, Hashim E, Possmayer F 1997 Deleterious effect of tracheal obstruction on type II pneumocytes in fetal sheep. Pediatr Res 41:473-479

14. Benachi A, Chailley-Heu B, Delezoide AL, Dommergues M, Brunelle F, Dumez Y, Bourbon JR 1998 Lung growth and maturation after tracheal occlusion in diaphragmatic hernia. Am J Respir Crit Care Med 157:921-927

15. O'Toole SJ, Sharma A, Karamanoukian HL, Holm B, Azizkhan RG, Glick PL 1996 Tracheal ligation does not correct the surfactant deficiency associated with congenital diaphragmatic hernia. J Pediatr Surg 31:546-550

16. Flageole H, Evrard VA, Piedboeuf B, Laberge JM, Lerut TE, Deprest JAM 1998 The plug-unplug sequence: an important step to achieve type II pneumocyte maturation in the fetal lamb model. J Pediatr Surg 33:299-303 
17. Bin Saddiq W, Piedboeuf B, Laberge JM, Gamache M, Petrov P, Hashim E, Manika A, Chen MF, Belanger S, Piuze G 1997 The effects of tracheal occlusion and release on type II pneumocytes in fetal lambs. J Pediatr Surg 32:834-838

18. Avery ME 1995 Historical overview of antenatal steroid use (commentaries). Pediatrics 95:133-135

19. Crowley P, Chalmers I, Keirse MJN 1990 The effects of corticosteroid administration before preterm delivery: an overview of the evidence from controlled trials. $\mathrm{Br} \mathrm{J}$ Obstet Gynecol 97:11-25

20. Asabe K, Hashimoto S, Suita S, Sueishi K 1996 Maternal dexamethasone treatment enhances the expression of surfactant apoprotein A in hypoplastic lung of rabbit fetuses induced by oligohydramnios. J Pediatr Surg 31:1369-1375

21. Rebello CM, Ikegami M, Polk DH, Jobe AH 1996 Postnatal lung responses and surfactant function after fetal or maternal corticosteroid treatment. J Appl Physiol 80:1674-1680

22. Polk DH, Ikegami M, Jobe AH, Sly P, Kohan R, Newnham J 1997 Preterm lung function after retreatment with antenatal betamethasone in preterm lambs. Am J Obstet Gynecol 176:308-315

23. Ikegami M, Polk D, Jobe A 1996 Minimum interval from fetal betamethasone treatment to postnatal lung responses in preterm lambs. Am J Obstet Gynecol 174:1408-1413

24. Zwikler MP, Peters TM, Michel RP 1994 Effects of pulmonary fibrosis on the distribution of edema: CT scanning and morphology. Am J Respir Crit Care Med 149:1266-1275

25. Zwikler MP, Iancu D, Michel RP 1994 Effects of pulmonary fibrosis on the distribution of edema: morphometric analysis. Am J Respir Crit Care Med 149:1276-1285

26. Vassilyadi M, Michel RP 1988 Pattern of fluid accumulation in $\mathrm{NO}_{2}$-induced pulmonary edema in dogs. A morphometric study. Am J Pathol 130:10-21

27. Tyler WS 1983 Small airways and terminal units: comparative subgross anatomy of lungs, pleuras, interlobular septa and distal airways. Am Rev Respir Dis 128(suppl):S32-S36

28. Piedboeuf B, Frenette J, Petrov P, Welty SE, Kazzaz JA, Horowitz S 1996 In vivo expression of intercellular adhesion molecule 1 in type II pneumocytes during hyperoxia. Am J Respir Cell Mol Biol 15:71-77

29. Dunhill MS 1962 Quantitative methods in the study of pulmonary pathology. Thorax $17: 320-328$

30. Kitterman JA 1996 The effects of mechanical forces on fetal lung growth. Clin Perinatol 23:727-739

31. Nardo L, Hooper SB, Harding R 1998 Stimulation of lung growth by tracheal obstruction in fetal sheep: relation to luminal pressure and lung liquid volume. Pediatr Res 43:184-190
32. Papadakis K, Luks FI, De Paepe ME, Piasecki GJ, Wesselhoeft CW 1997 Fetal lung growth after tracheal ligation is not solely a pressure phenomenon. J Pediatr Surg 32:347-351

33. Harding R, Hooper SB 1996 Regulation of lung expansion and lung growth before birth. J Appl Physiol 81:209-224

34. Finkelstein JN, 1990 Physiologic and toxicologic responses of alveolar type II cells. Toxicology 60:41-52

35. Kimber C, Spitz L, Cuschieri 1997 Current state of antenatal in utero surgical interventions. Arch Dis Child 76:F134-F139

36. Flageole H, Evrard VA, Vandenberghe K, Lerut TE, Deprest JAM 1997 Tracheoscopic endotracheal occlusion in the ovine model: technique and pulmonary effects. J Pediatr Surg 32:1328-1331

37. Vanderwall KJ, Bruch SW, Meuli M, Kohl T, Szabo Z, Adzick NS, Harrison MR 1996 Fetal endoscopic ('Fetendo') tracheal clip. J Pediatr Surg 31:1101-1104

38. Estes JM, MacGillivray TE, Hedrick MH, Adzick NS, Harrison MR 1992 Fetoscopic surgery for the treatment of congenital anomalies. J Pediatr Surg 27:950-954

39. Liggins GC 1969 Premature delivery of foetal lambs infused with glucocorticoids. J Endocrinol 45:515-523

40. Jenkin G, Sorgensen G, Thorburn GD 1985 Induction of premature delivery in sheep following infusion of cortisol to the fetus I. The effect of maternal administration of progestagens. Can J Physiol Pharmacol 63:500-508

41. Ikegami M, Jobe AH, Newnham J, Polk DH, Willet KE, Sly P 1997 Repetitive prenatal glucocorticoids improve lung function and decrease growth in preterm lambs. Am J Respir Crit Care Med 156:178-184

42. Beers MF, Fisher AB 1992 Surfactant protein C: a review of its unique properties and metabolism. Am J Physiol 263:L151-L160

43. Ballard PL, Ertsey R, Gonzales LW, Gonzales J 1996 Transcriptional regulation of human pulmonary surfactant proteins SP-B and SP-C by glucocorticoids. Am J Respir Cell Mol Biol 14:599-607

44. Mendelson CR, Boggaram V 1991 Hormonal control of the surfactant system in fetal lung. Annu Rev Physiol 53:415-440

45. Mendelson CR, Alcorn JL, Gao E 1993 The pulmonary surfactant protein genes and their regulation in fetal lung. Semin Perinatol 17:223-232

46. Harrison MR, Mychaliska GB, Albanese CT, Jennings RW, Farrell JA, Hawgood S, Sandberg P, Levine AH, Lobo E, Filly RA 1998 Correction of congenital diaphragmatic hernia in utero. IX: fetuses with poor prognosis (liver herniation and low lung-to-head ratio) can be saved by fetoscopic temporary tracheal occlusion. J Pediatr Surg 33:1017-1023 